\title{
Cryptic diversity within the harmful dinoflagellate Akashiwo sanguinea in coastal Chinese waters is related to differentiated ecological niches
}

\author{
Luo Zhaohe ${ }^{1}$, Yang Weidong ${ }^{2}$, Leaw Chui Pin ${ }^{3}$, Pospelova Vera ${ }^{4}$, Bilien Gwenael ${ }^{5}$, Liow Guat Ru ${ }^{3}$, \\ Lim Po Teen ${ }^{3}$, Gu Haifeng ${ }^{1, *}$
}

${ }^{1}$ Third Institute of Oceanography, SOA, Xiamen, 361005, China

${ }^{2}$ College of Life Science and Technology, Jinan University, Guangzhou 510632, China

${ }^{3}$ Bachok Marine Research Station, Institute of Ocean and Earth Sciences, University of Malaya, 16310 Bachok, Kelantan, Malaysia

${ }^{4}$ School of Earth and Ocean Sciences, University of Victoria, OEASB A405, P. O. Box 170016 STN

CSC, Victoria, British Columbia, V8W 2Y2, Canada

${ }^{5}$ Ifremer, LER BO, Station de Biologie Marine, Place de la Croix, BP40537, F-29185 Concarneau

Cedex, France

* Corresponding author : Zhaohe Luo, email address : guhaifeng@tio.org.cn

\begin{abstract}
:
Blooms of the harmful dinoflagellate Akashiwo sanguinea are responsible for the mass mortality of fish and invertebrates in coastal waters. This cosmopolitan species includes several genetically differentiated clades. Four clonal cultures were established by isolating single cells from Xiamen Harbour (the East China Sea) for morphological and genetic analyses. The cultures displayed identical morphology but were genetically different, thus revealing presence of cryptic diversity in the study area. New details of the apical structure complex of Akashiwo sanguinea were also found. To investigate whether the observed cryptic diversity was related to environmental differentiation, 634 cells were obtained from seasonal water samples collected from 2008 to 2012 . These cells were sequenced by single-cell PCR. For comparison with Chinese material, additional large subunit ribosomal DNA sequences were obtained for three established strains from Malaysian and French waters. To examine potential ecological differentiation of the distinct genotypes, growth responses of the studied strains were tested under laboratory conditions at temperatures of $12^{\circ} \mathrm{C}$ to $33^{\circ} \mathrm{C}$. These experiments showed four distinct ribotypes of $A$. sanguinea globally, with the ribotypes $A$ and $B$ co-occuring in Xiamen Harbour. Ribotype A of $A$. sanguinea was present year-round in Xiamen Harbour, but it only bloomed in the winter and spring, thus corresponding to the winter type. In contrast, A. sanguinea ribotype B bloomed only in the summer, corresponding to the summer type. This differentiation supports the temperature optimum conditions that were established for these two ribotypes in the laboratory. Ribotype A grew better at lower temperatures compared to ribotype B which preferred higher temperatures. These findings support the idea that various ribotypes of $A$. sanguinea correspond to distinct ecotypes and allopatric speciation occurred in different climatic regions followed by dispersal.
\end{abstract}




\section{Highlights}

- Four ribotypes of Akashiwo sanguinea are recovered. Two Akashiwo sanguinea ribotypes co-exist in Xiamen Harbour. Ribotypes of Akashiwo sanguinea are related to two distinct ecotypes in Xiamen Harbour. New details of the apical structure complex of $A$. sanguinea are reported.

Keywords: Biogeography, Cryptic species, Gymnodinium sanguineum, Seasonal occurrence, Speciation 


\section{Introduction}

By definition, cryptic species are morphologically indistinguishable despite being genetically different (Bickford et al., 2007). They are classified as one nominal species but some populations are reproductively isolated. Thus the isolated populations belong to different biological species. Cryptic species have long been recognized (e.g., Montresor et al., 2003), but only recently the speed of discovery has accelerated due to sequencing technology. Cryptic species have been reported in numerous marine organisms, including unicellular protists (e.g., picocyanobacteria (Farrant et al., 2016), prasinophytes (Šlapeta et al., 2006), coccolithophores (Saez et al., 2008), foraminifera (Darling et al., 2000), diatoms (Amato and Montresor, 2008), and dinoflagellates (Montresor et al., 2003)), macroalgae (e.g., red algae (Payo et al., 2013; Muangmai et al., 2016)), and marine animals (e.g., scyphozoans (Dawson and Jacobs, 2001) and rotifers (Suatoni et al., 2006; Montero-Pau et al., 2011)).

Marine micro-eukaryotes often have large census population sizes and high dispersal potential. Therefore, they have been considered to have a cosmopolitan distribution, as postulated by the "everything is everywhere" hypothesis (Baas-Becking, 1934; Finlay, 2002). Allopatric speciation, however, does occur in unicellular protists, e.g. in marine planktonic diatom Chaetoceros socialis (Degerlund et al., 2012), in some planktonic foraminifera with bipolar distributions (Darling et al., 2004), and globally distributed diatoms Pseudonitzschia pungens (Casteleyn et al. 2010). Genetic differentiation within species at small geographic scales has also been previously reported, e.g. Skeletonema marinoi (Godhe et al. 2016).

Another mechanism for cryptic speciation is sympatric speciation, i.e. speciation that occurs at the same location due to niche separation, with ecological sympatric speciation 
being one of the most important. Within the highly-dispersed planktonic foraminifera, reproductive mechanisms and behavior rather than geographic barriers play important roles in cryptic speciation (de Vargas et al., 1999). Many studies have also shown that cryptic marine species are ecophysiologically distinct (Finlay, 2004; Lowe et al., 2007; Rissler and Apodaca, 2007; Chen and Hare, 2008; De Meester et al., 2011; Muangmai et al., 2016), suggesting that theyoccupy specialized niches to allow for their co-occurrence. This ecological niche separation allows cryptic species to survive optimal environmental requirements, including biotic factors such as predation, competition, food resources in addition to abiotic habitat parameters (Grinnell, 1917; Hutchinson, 1957; Colwell and Rangel, 2009).

Although it is crucial to identify cryptic species accurately, this is often difficult to achieve. For example, the foraminiferan Orbulina universa is widely used as a stratigraphic and paleoclimatic indicator species, but it has been reported to include three hidden species with distinctly different distributional patterns (de Vargas et al., 1999). The dinoflagellate Alexandrium tamarense species complex groups III and IV can co-occur in the same water column but group IV is toxic whereas group III is nontoxic. Exact identification of these different groups therefore is essential for harmful algal bloom monitoring (Genovesi et al., 2011).

The dinoflagellate Akashiwo sanguinea (Hirasaka) G. Hansen \& Moestrup was originally described as Gymnodinium sanguineum K. Hirasaka (Hirasaka, 1922). It is characterized by an apical structure complex that curves around the apex in a clockwise direction, and was therefore transferred out of Gymnodinium F. Stein that has a horseshoe-shape apical structure 
complex (Daugbjerg et al., 2000).The species forms massive blooms in Asia (Hirasaka, 1922; Wang et al., 2005; Yu and Hao, 2009), Europe (Voltolina, 1975; Voltolina et al., 1986; O'Boyle and McDermott, 2014), Australia (Hallegraeff 1992), North America (Robinson and Brown, 1983; White et al., 2014), and South America (Kahru et al., 2004). Blooms of $A$. sanguinea have been associated with mass mortalities of invertebrates and fish (Shumway, 1990; Kahru et al., 2004) as well as seabirds (Jessup et al., 2009).

On the Pacific coast of North America, Akashiwo sanguinea regularly forms blooms that are related to a specific ecotype. In Esquimalt Lagoon (British Columbia, Canada) the first $A$. sanguinea cells appear in late summer or early fall when water temperatures range between $11^{\circ} \mathrm{C}$ to $21^{\circ} \mathrm{C}$, but blooms are commonly observed in middle fall (October) when water temperature is $12^{\circ} \mathrm{C}$ (1974-1982; Robinson and Brown, 1983). A single LSU sequence (AF260397) of A. sanguinea, collected from Esquimalt Lagoon is now available, and it could be associated with the autumn blooms in this lagoon. Blooms of Akashiwo sanguinea were also recorded in Monterey Bay (California, USA) in September 2006 with sea surface temperatures at $15^{\circ} \mathrm{C}$ (Kudela et al., 2008), and along the Oregon coast in OctoberNovember 2009 when water temperatures are at $12-14{ }^{\circ} \mathrm{C}$ (Du et al., 2011). The low water temperatures during the bloom periods suggest that they belong to the winter ecotype although molecular information on these cells is unavailable. Isolated strains from these blooms can growbetween $10{ }^{\circ} \mathrm{C}$ and $15^{\circ} \mathrm{C}$, but have an upper temperature limit of $30{ }^{\circ} \mathrm{C}$ to $33{ }^{\circ} \mathrm{C}$ (Boyd et al., 2013), similar to the ecophysiological strain of $A$. sanguinea from Japan (Matsubara et al., 2007). 
Tang and Gobler (2015) found several ribotypes of Akashiwo sanguinea that corresponded to different geographic origins (). Its presence has been reported in temperate, sub-tropical and tropical water columns throughout the year despite major differences among the environmental conditions (Badylak et al., 2014; Koening et al., 2014; Reñé et al., 2015). Cryptic speciation among the ribotypes has not been previously reported on this species. Preliminary observations show that A. sanguinea blooms regularly in Xiamen Harbour and two ribotypes are present. The scientific objective of this work is to examine the ribotypes of A. sanguinea from Xiamen Harbour through detailed morphological, genetic and ecophysiological analyses of cultured isolates and by following ribotype distribution throughout two annual cycles using single cell PCR techniques in the field.

\section{Materials and methods}

\subsection{Sample collection}

Xiamen Harbour is a $275 \mathrm{~km}^{2}$ semi-enclosed embayment that is located in the Strait of Taiwan between the South and East China Seas (Fig. S1). Sea-surface temperatures in Xiamen Harbour range from $10{ }^{\circ} \mathrm{C}$ in January to $31.5^{\circ} \mathrm{C}$ in July (Fig. S2).

To examine the morphology and growth response of Akashiwo sanguinea to variations in temperatures, four monoclonal cultures (strains ASXM02, ASXM29, ASXM165, and GSXM02) were established by isolating single cells using drawn-out Pasteur pipettes and several washes with droplets of sterile seawater. Four strains were established as cultures and identified on the basis of both morphology and molecular sequences. Cultures were 
maintained in f/2-Si medium (Guillard and Ryther, 1962) at $20{ }^{\circ} \mathrm{C}$, with an irradiance of 90 $\mu \mathrm{mol}$ photons $\cdot \mathrm{m}^{-2} \cdot \mathrm{s}^{-1}$ and a light: dark cycle of $12 \mathrm{~h}: 12 \mathrm{~h}$, from now on called "standard culture conditions."

In addition, one strain (Isolate 1184) was established from a plankton sample from Lagoon La Palme (France) $\left(42.966^{\circ} \mathrm{N}, 3.006^{\circ} \mathrm{E}\right)$ that was collected on October 28,2009 , and two strains (AsTm08, AsTm09) were obtained from a single water sample collected in Kelantan, Malaysia $\left(06^{\circ} 14^{\prime} 37.15^{\prime \prime}\right.$, $102^{\circ} 05^{\prime} 32.31$ "E) on July 26, 2015 (Fig. S1).

To investigate seasonal occurrence of Akashiwo sanguinea and its corresponding ribotypes, both bloom and monthly water samples were collected in Xiamen Harbour. Two bloom samples of A. sanguinea were collected in March 2008 and January 2009 respectively. Subsequently, seawater samples were collected at a monthly interval from May 2010 to May 2012 with the exception of July, 2011 when two samples were collected due to the bloom breakout. Cell density in six samples was low, thus less than 10 cells were isolated, but in other samples, from >10 to 62 cells were isolated. Single-cell PCR was performed on these isolated cells (634 total) to determine their ribotypes (see 2.3 below).

\subsection{Morphological studies}

Vegetative cells were examined under a Zeiss Axio Imager microscope (Carl Zeiss, Göttingen, Germany) with differential interference illumination. Light micrographs were obtained using a Zeiss Axiocam HRc digital camera. Cells in mid-exponential growth phase were fixed with 5\% Lugol's solution, and cell size was measured at 400× magnification. 
Four strains of A. sanguinea (two ribotype A and two ribotype B) and two bloom samples were examined in detail under a scanning electron microscope (SEM). Mid-exponential batch cultures or bloom samples $(600 \mu \mathrm{L})$ were fixed for $1 \mathrm{~h}$ at $4{ }^{\circ} \mathrm{C}$ with $4 \% \mathrm{OsO}_{4}(200 \mu \mathrm{L})$ prepared with filtered seawater. The material was then dehydrated in an ethanol series $(10,30$, 50, 70 and 90\%), followed by three treatments in $100 \%$ ethanol (10 min at each step), and critical point drying (K850 Critical Point Dryer, Quorum/Emitech, West Sussex, UK). Dried samples were sputter-coated with gold, and examined using a LEO 1530 Gemini SEM (Zeiss/LEO, Oberkochen, Germany).

\subsection{Molecular analysis}

To infer the molecular phylogeny and determine the pair-wise distance of available Akashiwo sanguinea strains, partial D1-D2 of the LSU rDNA and ITS sequences were amplified by primers D1R and D2C (Scholin et al., 1994) and primers ITSA and ITSB (Adachi et al., 1996). To determine the ribotypes of A. sanguinea from the field samples, partial D1-D2 of LSU rDNA sequences were also amplified. Single cells of A. sanguinea were isolated with an inverted microscope (Motic, Xiamen, China) immediately upon arrival in the laboratory, and they were transferred into a $200 \mu \mathrm{L}$ PCR tube followed by several washes with sterilized distilled water. The PCR reaction procedure was 4 min at $94{ }^{\circ} \mathrm{C}$, followed by 25 cycles of $1 \mathrm{~min}$ at $94{ }^{\circ} \mathrm{C}, 2 \mathrm{~min}$ at $45^{\circ} \mathrm{C}, 3 \mathrm{~min}$ at $72{ }^{\circ} \mathrm{C}$, and final extension of $7 \mathrm{~min}$, at $72{ }^{\circ} \mathrm{C}$. PCR products were sequenced directly in both directions using the ABI Big-Dye dye-terminator technique (Applied Biosystems, Foster City, CA, USA), according to 
the manufacturer's recommendations.

\subsection{Phylogenetic analysis}

Newly obtained partial LSU rDNA sequences were first aligned with those of related species available in GenBank (Table S1) using 'BioEdit' v7.0.0 (Hall, 1999), and then using Mafft (Katoh et al., 2005). Levanderina fissa (Levander) Ø. Moestrup, P. Hakanen, G. Hansen, N. Daugbjerg \& M. Ellegaard was selected as the outgroup. A general time reversible model $(\mathrm{GTR}+\mathrm{G})$ was selected with the Akaike information criterion using JmodelTest (Posada, 2008). Maximum likelihood-based analyses were conducted with 'RAxML' v7.2.6 (Stamatakis, 2006) using the model GTR $+\mathrm{G}$ on the T-REX web server (Boc et al., 2012). Node support was assessed with 1000 bootstrap replicates. A Bayesian reconstruction of the data matrix was performed with MrBayes 3.0b4 (Ronquist and Huelsenbeck, 2003) using the model GTR+G. Two independent analyses of four chains (one cold and three heated) were run with 1,000,000 cycles, sampled every 1000 cycle with an appropriate burnin of $10 \%$. A majority rule consensus tree was created in order to examine the posterior probabilities of each clade.

The ITS sequences of $A$. sanguinea obtained in the present study were aligned with those available in the GenBank using Mafft (Katoh et al., 2005) and saved as a NEXUS file. Simple uncorrected pair-wise (p) distance matrices were estimated with PAUP*4b10 software (Swofford, 2002). 


\subsection{Growth experiments}

Experiments on growth at various temperatures $\left(12,15,18,21,24,27,30\right.$ and $\left.33^{\circ} \mathrm{C}\right)$ were conducted in triplicate using $200 \mathrm{~mL}$ glass bottles with $100 \mathrm{~mL} \mathrm{f} / 2-\mathrm{Si}$ medium and an initial cell density of $\sim 500$ cells $\mathrm{mL}^{-1}\left(30 \mathrm{psu}, 90 \mu \mathrm{mol}\right.$ photons $\left.\cdot \mathrm{m}^{-2} \cdot \mathrm{s}^{-1}\right)$. Actively swimming cells of strains ASXM29 and ASXM165 were acclimated over a period of 15 days to neighbouring temperatures successively, at steps no greater than $3{ }^{\circ} \mathrm{C}$ at a time. The light: dark cycle in all experiments was 12:12 h. For sampling, $0.5 \mathrm{~mL}$ of cells were removed from the culture at 3-day intervals and fixed in Lugol's solution. Each sample was transferred to a Sedgwick-Rafter chamber and a minimum of 200 cells per sample were counted.

Maximum number of divisions per day (k) was determined for the exponential growth phase, using the formula $\mathrm{k}=\left[\ln \left(\mathrm{N}_{\mathrm{t}} / \mathrm{N}_{0}\right) / \Delta \mathrm{t}\right] / 0.6931$, where $\mathrm{N}_{0}$ is the population size at the beginning of a time interval, $\mathrm{N}_{\mathrm{t}}$ is the population size at the end of a time interval, and $\Delta t$ is the length of the time interval.

\section{Results}

\subsection{Morphology}

The morphology of the examined isolates agreed in most details with the description of the species Akashiwo sanguinea by Hirasaka (1922). Both ribotypes were indistinguishable in morphology but there were differences in size. Vegetative cells of Akashiwo sanguinea strain ASXM165 (ribotype A) were 59-74 $\mu \mathrm{m}$ (mean= 65 $\pm 5 \mu \mathrm{m}, \mathrm{n}=20)$ long, 40-51 (mean= 45 \pm 4 $\mu \mathrm{m}, \mathrm{n}=20) \mu \mathrm{m}$ wide. Vegetative cells of A. sanguinea strain ASXM29 (ribotype B) were 
61-75 $\mu \mathrm{m}($ mean $=66 \pm 4 \mu \mathrm{m}, \mathrm{n}=20)$ long, 45-61 $\mu \mathrm{m}($ mean $=53 \pm 4 \mu \mathrm{m}, \mathrm{n}=20)$ wide. The cells were flattened in dorsoventral view. There were numerous ribbon-like chloroplasts located in the periphery of the cell (Fig. 1 A, B) and a spherical nucleus in the center of the cell (Fig. 1C). The sulcus was narrow in the intercingulum region due to the finger-like projection of the right epitheca, but it became wider in the posterior where it divided the hypotheca into two parts (Fig. 2A). The apical structure complex resembled a lasso originating from the right apex and curving around the apex in the anticlockwise direction, and ending just above the sulcus (Fig. 2B, C). The apical structure complex comprised three rows of vesicles with numerous small knobs in the middle row (Fig. 2D, E). The sulcus intruded the epitheca as a narrow furrow and nearly touched the start of the apical groove (Fig. 2B, C). The shape of the apical structure complex is illustrated in Fig. 3.

\subsection{Molecular analysis and phylogeny}

Two ribotypes of A. sanguinea were recovered from samples collected in Xiamen Harbour. The same ribotype shared identical LSU rDNA and ITS sequences. For LSU sequences comparison, strain ASXM165 (ribotype A) shared identical sequences as those from Japan, Korea, New Zealand, South Africa, and Canada. Strain ASXM29 from Xiamen Harbour (ribotype B) shared an identical LSU rDNA sequence with strain GT6 from Singapore and AsTM08 from Malaysia. Another Malaysian strain AsTM09 differed from a Korea strain GSW0207, AsTM08 with two and 16 nucleotide polymorphism (99.73\% and 97.91\% similarity, respectively). Strain ASXM02 differed from ASXM29 with 25 nucleotide 
polymorphism (95.87\% similarity), and they differed from strain CCMP1593 (ribotype C) from USA with 12 and 23 nucleotide polymophism (98.02\% and 96.2\% similarity, respectively), differed from the French strain isolate 1184 (ribotype D) with 10 and 21 nucleotide polymophism ( $98.35 \%$ and $96.53 \%$ similarity, respectively).

Maximum likelihood and Bayesian inference based on LSU rDNA sequences generated similar phylogenetic trees. Four well-resolved ribotypes were recovered in Akashiwo sanguinea. Ribotype A included strains from East Asia, South Africa, New Zealand, and Canada, whereas ribotype B included strains from East Asia, Singapore, Malaysia and Mexico Pacific. Ribotypes C and D included strains exclusively from Atlantic coast of USA and the Mediterranean Sea, respectively (Fig. 4).

For ITS sequence comparison, strain ASXM165 shared the identical sequence with strain AC215 (FJ823503) from Normandy ( France), and differed from strain ASXM29 with 216 nucleotide polymophism (63.14\%) and from strain CCMP1593 with 149 and 225 nucleotide polymophism (74.49\% and $62.44 \%$ similarity, respectively). Uncorrected genetic distance based on ITS sequences among the ribotypes ranged from 0.14 to 0.27 (Table 1).

\subsection{Temporal distribution}

A total of 634 A. sanguinea cells from the bloom and seasonal samples were isolated and sequenced. Among these, 459 belonged to ribotype A and 175 belonged to ribotype B. Ribotype A occurred in the water column throughout the year, and dominated the samples 
except in the summer (July to October, 2011). In contrast, ribotype B was observed only in May and from July to November, when it often dominated the samples(Fig. 5). Both ribotypes can co-occur in the seasonal water samples but are never together in the same bloom samples. Ribotype A bloomed at temperatures between $13{ }^{\circ} \mathrm{C}$ and $21^{\circ} \mathrm{C}$ (January, March, and May), whereas ribotype B bloomed only in July when the temperature reached $30{ }^{\circ} \mathrm{C}$ in 2012 .

\subsection{Growth}

The strain of Akashiwo sanguinea (ASXM165, ribotype A) showed similar growth rates (0.36- 0.44 divisions $\mathrm{d}^{-1}$ ) at temperatures ranging between $12{ }^{\circ} \mathrm{C}$ and $30^{\circ} \mathrm{C}$, but ceased to grow at $33^{\circ}$ C. Strain ASXM29 (ribotype B) showed similar growth rates (0.35-0.52 divisions $\left.\mathrm{d}^{-1}\right)$ between $18{ }^{\circ} \mathrm{C}$ and $33{ }^{\circ} \mathrm{C}$, but grew slowly at $15{ }^{\circ} \mathrm{C}\left(0.05\right.$ divisions $\left.\mathrm{d}^{-1}\right)$ and ceased to grow at $12{ }^{\circ} \mathrm{C}$ (Fig. 6).

\section{Discussion}

\subsection{Morphology and biogeography}

When defining the genus Akashiwo, Daugbjerg et al. (2000) adopted the morphology of a Japanese strain, and sequences of strains from Canada (ribotype A) and USA (ribotype C) were used. The new results (Figure 3), however, clarify the details of the apical structure complex for the first time, showing that it curves in an anticlockwise direction and that the short linear apical structure complex of Daugbjerg et al. (2000; fig. 2 F, G) is in fact a sulcal intrusion. The apical structure complex differs from the sulcal intrusion in that it comprises 
three elongated vesicles, one of which is ornamented with numerous small knobs. These subtle structures may have been overlooked in previous reports (e.g. Takayama, 1998). The genus definition of Akashiwo needs to be emended if the morphological features of Chinese strains can be confirmed on the type material from Japan.

Ribotypes A and B of Akashiwo sanguinea share indistinguishable morphology; however, morphological details of ribotypes $\mathrm{C}$ and $\mathrm{D}$, especially the apical structure complex, remain to be determined. The uncorrected genetic distances based on ITS sequences among $A$. sanguinea ribotypes ranged from 0.14 to 0.27 , which is much larger than the threshold value (0.04) for differentiating free-living dinoflagellates at the inter-specific level (Litaker et al., 2007). Therefore, A. sanguinea may be a "species complex", and it comprises at least four morphologically hidden but genetically distinct entities. Ribotype A of A. sanguinea appears to be cosmopolitan, as it is recognised in Asia (China, Korea, and Japan), Europe (Normandy, France), Australia, Africa (South Africa), and North America (Canada), based on sequences publicly available in GenBank. Ribotype B of A. sanguinea has a narrower distribution, as it is recorded from the Pacific including South Korea, China, Mexico, Singapore and Malaysia (based on available sequences; present study). In contrast, ribotypes C and D appeared to be restricted to the Atlantic USA and the Mediterranean Sea, respectively (Reñé et al. 2015; Tang and Gobler, 2015; present study). 


\subsection{Ecological speciation}

Ribotype A of Akashiwo sanguinea is globally distributed and is at the basal position in molecular phylogeny, potentially presenting a basal type. Other ribotypes may be derived from ribotype Abecause they have narrower distributions. The diversification of A. sanguinea ribotype $\mathrm{B}$ could be attributed to adaption to high temperatures as this ribotype occurs in tropical waters and during warm seasons of temperate regions (Kim and Kim, 2007; present study). Higher temperatures are also preferred by ribotype B in culture experiment (Fig. 6). Growth rate variation at intra-specific level was also reported from a single bloom sample of A. sanguinea and with the same trend (Menden-Deuer and Montalbano, 2015). Therefore, the ecophysiological experiments in the present study are still informative although only a few strains were tested. A similar genetic differentiation has also been reported for the diatom Thalassiosira rotula, which was found to be related to environmental and ecological selection rather than to dispersal potential (Whittaker and Rynearson, 2017).

Sexual reproduction has been reported in A. sanguinea ribotype C (Tang and Gobler, 2015); however, compelling evidence of sexual reproduction in other ribotypes is unavailable. Intermediate sequences between ribotypes A and B were not detected in the present study, suggesting that hybridization is rare. These various ribotypes might represent different species as suggested in Alexandrium tamarense species complex (John et al. 2014), but much more evidence is needed, especially data from mating experiments.

Two potential mechanisms may be responsible for the co-occurrence of $A$. sanguinea ribotypes A and B in Xiamen Harbour: ecological sympatric speciation or allopatric speciation 
followed by subsequent invasion. The second mechanism is considerably more likely, taking into account the widespread distributions of these ribotypes along the Pacific coasts. The presence of ribotype A in the Canadian Pacific (Daugbjerg et al., 2000) indicates that it is related to an ecotype adapted to low temperature, which is consistent with its regular winter blooms in Xiamen Harbour. The presence of ribotype B in the tropical Malaysia indicates that this is an ecotype adapted to high temperature.It is possible that allopatric speciation occurred in different climatic regions, followed by dispersal that might explain the co-existence of ribotypes A and B in Xiamen Harbour and along the southern South Korean coast.

The strain of A. sanguinea from Hakozaki Harbour (Japan, November 2002) was able to grow at temperatures between $10{ }^{\circ} \mathrm{C}$ and $30{ }^{\circ} \mathrm{C}$, and survived for 50 days at $5{ }^{\circ} \mathrm{C}$ (Matsubara et al., 2007). This suggests that the strain belongs to the winter ecotype. The dinoflagellate Akashiwo sanguinea was described from bloom samples in Japan, collected during December 1921 when seawater temperature was $13-15^{\circ} \mathrm{C}$ (Hirasaka, 1922). To date, only ribotype A has been reported in Japan, and it was isolated from Hokkaido in August 2003 (Takano and Horiguchi, 2006), suggesting that ribotype A may represent true A. sanguinea.Ribotype C of Akashiwo sanguinea was exclusively recorded on the east coast of the United States, but whether it corresponds to an ecotype is not clear. In the Gulf of Mexico, A. sanguinea blooms were reported in February and June (Badylak et al., 2014). Molecular information from this region is unavailable, but it likely belongs to ribotype $\mathrm{C}$ based on one strain from Florida that has been sequenced. In Chesapeake Bay, A. sanguinea blooms in the summer (Bockstahler and Coats, 1993) and one strain from Chesapeake Bay corresponds to ribotyp C (Tang and 
Gobler, 2015), also suggesting that this ribotype corresponds to the warm ecotype. Strains of A. sanguinea ribotype D from the Mediterranean Sea were isolated in later October and early August (Reñé et al., 2015; present study); those ecotypes remain to be determined.

Theoretically, the coexistence of sympatric species is possible when species have at least some differences in food choice, physiological responses, or habitat (Gause, 1932; Muangmai et al., 2016; Sohm et al., 2016). The occurrence of A. sanguinea ribotype A in Xiamen Harbour throughout the year suggest that the niches of the two ribotypes might overlap. In laboratory growth experiments ribotype B can grow at $18{ }^{\circ} \mathrm{C}$ and $21^{\circ} \mathrm{C}$, but they never appear in the spring samples, suggesting that the niche of ribotype B was not fully realized. Ribotype A blooms at temperatures ranging from $13{ }^{\circ} \mathrm{C}$ to $21^{\circ} \mathrm{C}$, in contrast, ribotype $\mathrm{B}$ blooms at $30{ }^{\circ} \mathrm{C}$, supporting the ecological competitive exclusion principle that coexisting species must have partitioned their niches in order to minimize an overlap and reduce competition (Hardin, 1960). Ecological segregation may also exist in the Alexandrium tamarense species complex Groups III and IV that co-occurin a Mediterranean lagoon, since Group III blooms in May and Group IV blooms in October (Genovesi et al., 2011).

Besides temperature, A. sanguinea ribotypes may also differ in other ecophysiological responses. Mixotrophy was reported in Akashiwo sanguinea preying on a variety of cryptophytes and other dinoflagellates (Jeong et al., 2005), and it could be infected by parasites such as species of the genus Amoebophrya, which is further regulated by ciliate microzooplankton (Johansson and Coats, 2002). Whether A. sanguinea ribotypes A and B differ in the prey selection and susceptibility to parasites remains to be determined. 
In conclusion, the present work has shown that the bloom-forming dinoflagellate Akashiwo sanguinea comprises four ribotypes of which ribotypes A and B co-occur in Xiamen Harbour. The two ribotypes are related to differentiated ecological niches and bloomed in Xiamen Harbour during winter and summer respectively. Ecotypes of the other ribotypes require further investigations.

\section{Acknowledgements}

Two anonymous reviewers are thanked for constructive suggestions that greatly improved the manuscript. Petra Mudie was thanked for correcting the English. This work was supported by National Natural Science Foundation of China (41676117) and China-ASEAN Maritime Cooperation Fund.

\section{References}

Adachi, M., Sako, Y., Ishida, Y., 1996. Analysis of Alexandrium (Dinophyceae) species using sequences of the 5.8S ribosomal DNA and internal transcribed spacer regions. J. Phycol. 32, $424-432$.

Amato, A., Montresor, M., 2008. Morphology, phylogeny, and sexual cycle of Pseudo-nitzschia mannii sp. nov. (Bacillariophyceae): a pseudo-cryptic species within the $P$. pseudodelicatissima complex. Phycologia 47, 487-497.

Baas-Becking, L.G.M., 1934. Geobiologie; of inleiding tot de milieukunde WP Van Stockum \& Zoon NV.

Badylak, S., Phlips, E.J., Mathews, A.L., 2014. Akashiwo sanguinea (Dinophyceae) blooms in 
a sub-tropical estuary: An alga for all seasons. Plankton Benthos Res. 9, 147-155.

Bickford, D., Lohman, D.J., Sodhi, N.S., Peter, K.L.Ng., Rudolf, M., Kevin, W., Krista, K.I., Indraneil, D., 2007. Cryptic species as a window on diversity and conservation. Trends Ecol. Evol. 22, 148-155.

Boc, A., Diallo, A.B., Makarenkov, V., 2012. T-REX: a web server for inferring, validating and visualizing phylogenetic trees and networks. Nucleic Acids Res. 40, W573-W579.

Bockstahler, K., Coats, D., 1993. Grazing of the mixotrophic dinoflagellate Gymnodinium sanguineum on ciliate populations of Chesapeake Bay. Mar. Biol. 116, 477-487.

Boyd, P.W., Rynearson, T.A., Armstrong, E.A., Fu, F., Hayashi, K., Hu, Z., Hutchins, D.A., Kudela, R.M., Litchman, E., Mulholland, M.R., 2013. Marine phytoplankton temperature versus growth responses from polar to tropical waters-outcome of a scientific community-wide study. PloS ONE 8, e63091.

Casteleyn, G., Leliaert, F., Backeljau, T., Debeer, A.E., Kotaki, Y., Rhodes, L., Lundholm, N., Sabbe, K., Vyverman, W., 2010. Limits to gene flow in a cosmopolitan marine planktonic diatom. PNAS 107, 12952-12957.

Chen, G., Hare, M.P., 2008. Cryptic ecological diversification of a planktonic estuarine copepod, Acartia tonsa. Mol. Ecol. 17, 1451-1468.

Colwell, R.K., Rangel, T.F., 2009. Hutchinson's duality: the once and future niche. PNAS 106, 19651-19658.

Darling, K.F., Kucera, M., Pudsey, C.J., Wade, C.M., 2004. Molecular evidence links cryptic diversification in polar planktonic protists to Quaternary climate dynamics. PNAS 101, 
7657-7662.

Darling, K.F., Wade, C.M., Stewart, I.A., Kroon, D., Dingle, R., Brown, A.J.L., 2000.

Molecular evidence for genetic mixing of Arctic and Antarctic subpolar populations of planktonic foraminifers. Nature 405, 43-47.

Daugbjerg, N., Hansen, G., Larsen, J., Moestrup, Ø., 2000. Phylogeny of some of the major genera of dinoflagellates based on ultrastructure and partial LSU rDNA sequence data, including the erection of three new genera of unarmoured dinoflagellates. Phycologia 39, 302-317.

Dawson, M.N., Jacobs, D.K., 2001. Molecular evidence for cryptic species of Aurelia aurita (Cnidaria, Scyphozoa). Biol. Bull. 200, 92-96.

De Meester, N., Derycke, S., Bonte, D., Moens, T., 2011. Salinity effects on the coexistence of cryptic species: a case study on marine nematodes. Mar. Biol. 158, 2717-2726.

de Vargas, C., Norris, R., Zaninetti, L., Gibb, S.W., Pawlowski, J., 1999. Molecular evidence of cryptic speciation in planktonic foraminifers and their relation to oceanic provinces. PNAS 96, 2864-2868.

Degerlund, M., Huseby, S., Zingone, A., Sarno, D., Landfald, B., 2012. Functional diversity in cryptic species of Chaetoceros socialis Lauder (Bacillariophyceae). J. Plankton Res. 34, 416-431.

Du, X., Peterson, W., McCulloch, A., Liu, G., 2011. An unusual bloom of the dinoflagellate Akashiwo sanguinea off the central Oregon, USA, coast in autumn 2009. Harmful Algae 10, $784-793$. 
Farrant, G.K., Doré, H., Cornejo-Castillo, F.M., Partensky, F., Ratin, M., Ostrowski, M., Pitt, F.D., Wincker, P., Scanlan, D.J., Iudicone, D., Acinas, S.G., Garczarek, L., 2016. Delineating ecologically significant taxonomic units from global patterns of marine picocyanobacteria.

PNAS 113, 3365-3374

Finlay, B.J., 2002. Global dispersal of free-living microbial eukaryote species. Science 296, $1061-1063$.

Finlay, B.J., 2004. Protist taxonomy: an ecological perspective. Philos. Trans. R. Soc. Lond, Ser. B. 359, 599-610.

Gause, G.F., 1932. Experimental studies on the struggle for existence. J. Exp. Biol. 9, $389-402$.

Genovesi, B., Shin-Grzebyk, M.S., Grzebyk, D., Laabir, M., Gagnaire, P.A., Vaquer, A., Pastoureaud, A., Lasserre, B., Collos, Y., Berrebi, P., 2011. Assessment of cryptic species diversity within blooms and cyst bank of the Alexandrium tamarense complex (Dinophyceae) in a Mediterranean lagoon facilitated by semi-multiplex PCR. J. Plankton Res. 33, 405-414. Godhe, A., Sjöqvist, C., Sildever, S., Sefbom, J., Harðardóttir, S., Bertos-Fortis, M., Bunse, C., Gross, S., Johansson, E., Jonsson, P. R., Khandan, S., Legrand, C., Lips, I., Lundholm, N., Rengefors, K. E., Sassenhagen, I., Suikkanen, S., Sundqvist, L., Kremp, A., 2016, Physical barriers and environmental gradients cause spatial and temporal genetic differentiation of an extensive algal bloom. J. Biogeogr., 43, 1130-1142.

Grinnell, J., 1917. The niche-relationships of the California Thrasher. The Auk. 34, 427-433. Guillard, R.R.L., Ryther, J.H., 1962. Studies of marine planktonic diatoms. I. Cyclotella nana 
Hustedt and Detonula confervacea Cleve. Can. J. Microbiol. 8, 229-239.

Hall, T.A., 1999. BioEdit: a user-friendly biological sequence alignment editor and analysis program for Windows 95/98/NT. Nucleic Acids Symp. Ser. 41, 95-98.

Hallegraeff, G.M., 1992. Harmful algal blooms in the Australian region. Mar. Pollut. Bull. 25, 186-190.

Hardin, G., 1960. The competitive exclusion principle. Science 131, 1292-1297.

Hirasaka, K., 1922. On a case of discolored sea-water. Annot. Zool. Japan 10, 161-164.

Hutchinson, G.E., 1957. Concluding remarks. Cold Spr. Harb. Symp. Quant. Biol. 22, 415-427.Jeong, H.J., Du, Y.Y., Park, J.Y., Kim, J.H., Park, J.Y., Kim, S., Lee, S.H., Ha, J.H., Yih, W.H., 2005. Feeding by phototrophic red-tide dinoflagellates, five species newly revealed and six species previously known to be mixotrophic. Aquat. Microb. Ecol. 40, $133-150$.

Jessup, D.A., Miller, M.A., Ryan, J.P., Nevins, H.M., Kerkering, H.A., Mekebri, A., Crane, D.B., Johnson, T.A., Kudela, R.M., 2009. Mass stranding of marine birds caused by a surfactant-producing red tide. PloS ONE 4, e4550.

Johansson, M., Coats, D.W., 2002. Ciliate grazing on the parasite Amoebophrya sp. decreases infection of the red-tide dinoflagellate Akashiwo sanguinea. Aquat. Microb. Ecol. 28, 69-78. John, U., Litaker, R.W., Montresor, M., Murray, S., Brosnahan, M.L., Anderson, D.M., 2014. Formal revision of the Alexandrium tamarense species complex (Dinophyceae) taxonomy: The introduction of five species with emphasis on molecular-based (rDNA) classification. Protist 165, 779-804. 
Kahru, M., Michell, B.G., Diaz, A., Miura, M., 2004. MODIS detects a devastating algal bloom in Paracas Bay, Peru. EAS Trans. AGU 85, 465-472.

Katoh, K., Kuma, K., Toh, H., Miyata, T., 2005. MAFFT version 5: improvement in accuracy of multiple sequence alignment. Nucleic Acids. Res. 33, 511-518.

Kim, K., Kim, C., 2007. Phylogenetic relationships among diverse dinoflagellate species occurring in coastal waters off Korea inferred from large subunit ribosomal DNA sequence data. Algae 22, 57-67.

Koening, M.L, Flores Montes, M.J, Eskinazi Leça, E., Tiburcio, A.S.X.S., 2014. New record of Akashiwo sanguinea (Dinophyta) in the tropical estuarine waters of Northeastern Brazil (Western Atlantic). Brazilian J. Biol. 74, 191-198.

Kudela, R.M., Lane, J.Q., Cochlan, W.P., 2008. The potential role of anthropogenically derived nitrogen in the growth of harmful algae in California, USA. Harmful Algae 8, $103-110$.

Litaker, W.R., Vandersea, M.W., Kibler, S.R., Reece, K.S., Stokes, N.A., Lutzoni, F.M., Yonish, B.A., West, M.A., Black, M.N.D., Tester, P.A., 2007. Recognizing dinoflagellate species using ITS rDNA sequences. J. Phycol. 43, 344-355.

Lowe, C., Kemp, S., Diaz-Avalos, C., Montagnes, D.J.S., 2007. How does salinity tolerance influence the distributions of Brachionus plicatilis sibling species? Mar. Biol. 150, 377-386. Matsubara, T., Nagasoe, S., Yamasaki, Y., Shikata, T., Shimasaki, Y., Oshima, Y., Honjo, T., 2007. Effects of temperature, salinity and irradiance on the growth of the dinoflagellate Akashiwo sanguinea. J. Exp. Mar. Biol. Ecol. 342, 226-230. 
Menden-Deuer, S., Montalbano, A.L., 2015. Bloom formation potential in the harmful dinoflagellate Akashiwo sanguinea: clues from movement behaviors and growth characteristics. Harmful Algae 47, 75-85.

Montero-Pau, J., Ramos-Rodríguez, E., Serra, M., Gómez, A., 2011. Long-term coexistence of rotifer cryptic species. PloS ONE 6, e21530.

Montresor, M., Sgrosso, S., Procaccini, G., Kooistra, W.H.C.F., 2003. Intraspecific diversity in Scrippsiella trochoidea (Dinopbyceae): evidence for cryptic species. Phycologia 42, 56-70.

Muangmai, N., von Ammon, U., Zuccarello, G.C., 2016. Cryptic species in sympatry:

nonrandom small-scale distribution patterns in Bostrychia intricata (Ceramiales, Rhodophyta). Phycologia 55, 424-430.

O'Boyle, S., McDermott, G., 2014. Observations of a thin near surface layer in an estuarine environment: An exceptional bloom of the dinoflagellate Akashiwo sanguinea in the Lee estuary (Lough Mahon), Co. Cork, in September 2010. Deep-Sea Res. II (Top Stud. Oceanogr.) 101, 244-248

Payo, D.A., Leliaert, F., Verbruggen, H., D'hondt, S., Calumpong, H.P., De Clerck, O., 2013. Extensive cryptic species diversity and fine-scale endemism in the marine red alga Portieria in the Philippines. Proc. R. Soc. B. 280, 20122660.

Reñé, A., Camp, J., Garcés, E., 2015. Diversity and phylogeny of Gymnodiniales (Dinophyceae) from the NW Mediterranean Sea revealed by a morphological and molecular approach. Protist 166, 234-263.

Posada, D., 2008. jModelTest: phylogenetic model averaging. Mol. Biol. Evol. 25, 
$1253-1256$.

Rissler, L.J., Apodaca, J.J., 2007. Adding more ecology into species delimitation: ecological niche models and phylogeography help define cryptic species in the black salamander (Aneides flavipunctatus). Syst. Biol. 56, 924-942.

Robinson, M., Brown, L., 1983. A recurrent red tide in a British Columbia coastal lagoon. Can. J. Fish. Aquat. Sci. 40, 2135-2143.

Ronquist, F., Huelsenbeck, J.P., 2003. MrBayes 3: Bayesian phylogenetic inference under mixed models. Bioinformatics 19, 1572-1574.

Saez, A.G., Geisen, M., Quinn, P., Young, J.R., Medlin, L., 2008. Pseudo-cryptic speciation in coccolithophores. PNAS 100, 7163-7168.

Scholin, C.A., Herzog, M., Sogin, M., Anderson, D.M., 1994. Identification of group- and strain-specific genetic markers for globally distributed Alexandrium (Dinophyceae). II. Sequence analysis of a fragment of the LSU rRNA gene. J. Phycol. 30, 999-1011. Shumway, S.E., 1990. A review of the effects of algal blooms on shellfish and aquaculture. J. World Aquacult. Soc. 21, 65-104.

Šlapeta, J., López-García, P., Moreira, D., 2006. Global dispersal and ancient cryptic species in the smallest marine eukaryotes. Mol. Biol. Evol. 23, 23-29.

Sohm, J.A., Ahlgren, N.A., Thomson, Z.J., Williams, C., Moffett, J.W., Saito, M.A., Webb, E.A., Rocap, G., 2016. Co-occurring Synechococcus ecotypes occupy four major oceanic regimes defined by temperature, macronutrients and iron. The ISME J. 10, 333-345. Stamatakis, A., 2006. RAxML-VI-HPC: maximum likelihood-based phylogenetic analyses 
with thousands of taxa and mixed models. Bioinformatics 22, 2688-2690.

Suatoni, E., Vicario, S., Rice, S., Snell, T., Caccone, A., 2006. An analysis of species boundaries and biogeographic patterns in a cryptic species complex: The rotifer-Brachionus plicatilis. Mol. Phylogen. Evol. 41, 86-98.

Swofford, D.L., 2002. PAUP*. Phylogenetic analysis using parsimony (* and other methods), version 4. Sinauer Associates, Sunderland, Massachusetts, USA.

Takayama, H., 1998. Morphological and taxonomical studies on the free-living unarmored dinoflagellates occurring in the Seto Inland Sea and adjacent waters. PhD dissertation, University of Tokyo, Tokyo, $211 \mathrm{p}$.

Takano, Y., Horiguchi, T., 2006. Acquiring scanning electron microscopical, light microscopical and multiple gene sequence data from a single dinoflagellate cell. J. Phycol. 42, $251-256$.

Tang, Y.Z., Gobler, C.J., 2015. Sexual resting cyst production by the dinoflagellate Akashiwo sanguinea: a potential mechanism contributing to the ubiquitous distribution of a harmful alga. J. Phycol. 51, 298-309.

Voltolina, D., 1975. The phytoplankton of the lagoon of Venice: November 1971-November 1972. Pubbl. Staz. Zool. Napoli. 39, 206-340.

Voltolina, D., Beardall, J., Foster, P., 1986. The phytoplankton of Liverpool Bay (1977-1978). IV: Geographic distributions and seasonal variations. Nova Hedwigia 43, 11-28.

White AE, Watkins-Brandt KS, McKibben SM, Wood AM, Hunter M, Forster Z, Du X, Peterson, W.T., 2014. Large-scale bloom of Akashiwo sanguinea in the Northern California 
current system in 2009. Harmful Algae 37, 38-46.

Wang, J.H., Qing, Y.T., Li, Z.E., Huang, X., Chen, L., Lei, Y.W., Xu, L.G., You, S.P., 2005.

The environmental factor and cause of Gymnodinium sanguineum HAB in Nanji Islands

Preserved District. Mar. Sci. 29, 32-36 (in Chinese with English abstract).

Whittaker, K.A., Rynearson, T.A., 2017. Evidence for environmental and ecological selection in a microbe with no geographic limits to gene flow. PNAS 114, 2651-2656.

Yu, L., Hao, Y.J., 2009. Process analysis for harmful bloom of Akashiwo sanguinea in Sishili Bay of Yantai. Adv. Mar. Sci. 27, 516-522 (in Chinese with English abstract).

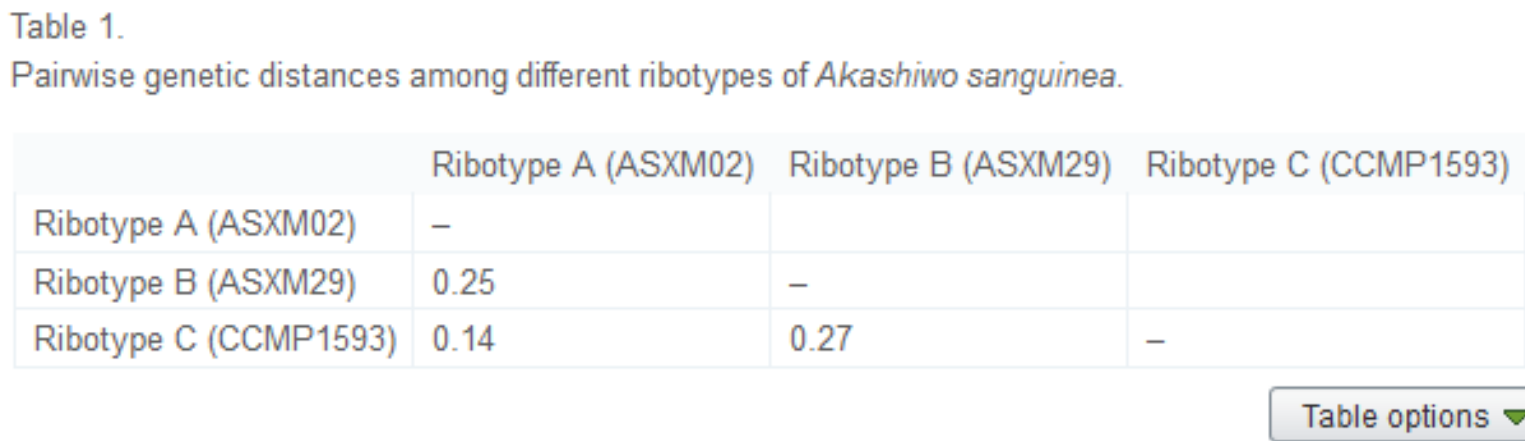


Figure 1. Light micrographs of Akashiwo sanguinea vegetative cells of strain ASXM29. (A-B)

Ventral and dorsal view showing numerous chloroplasts. (C) Ventral view showing the round nucleus (n) located in the middle part.

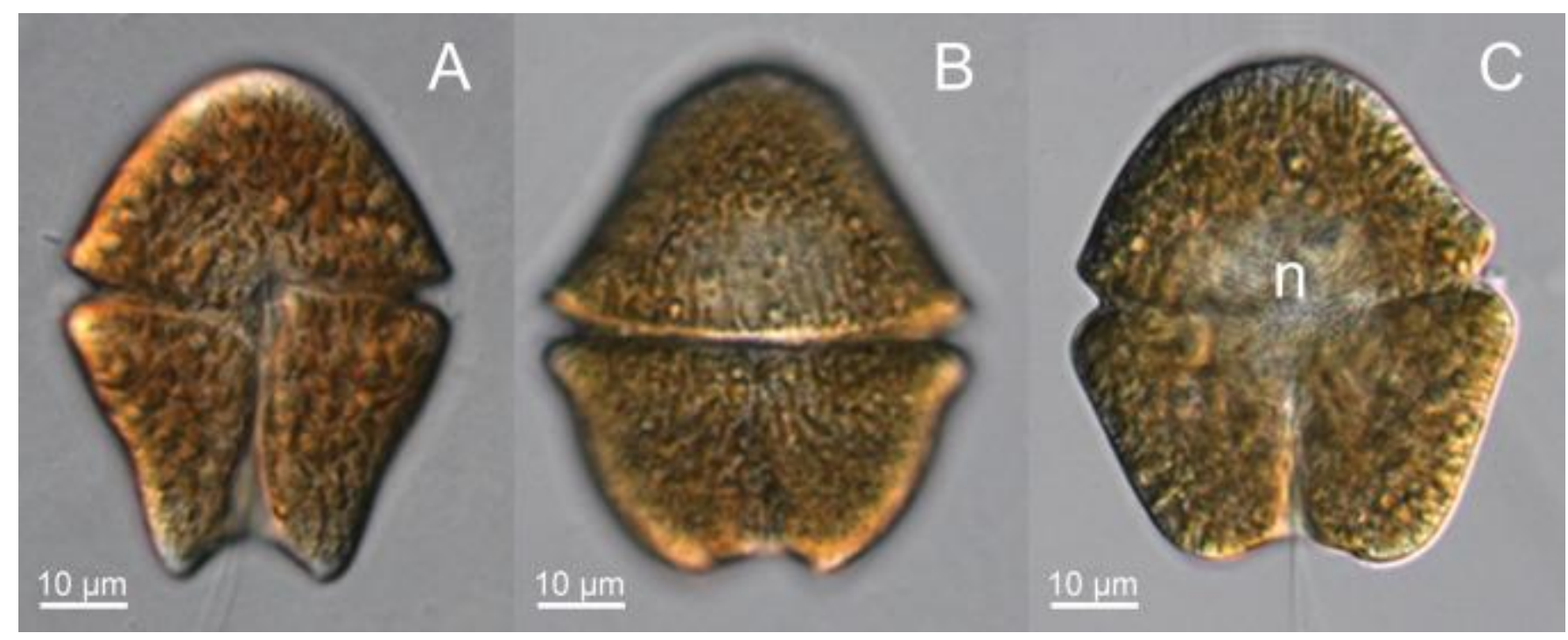


Figure 2. Scanning electron micrographs of Akashiwo sanguinea vegetative cells of strain ASXM29. (A) Ventral view. (B) Apical view showing the apical structure complex (arrows) and sulcal intrusion (arrowheads). (C-D) Detail of the sulcal intrusion (arrowheads) and the apical structure complex, showing three rows of vesicles (arrows). (E) Detail of the middle row of the apical structure complex showing numerous small knobs.
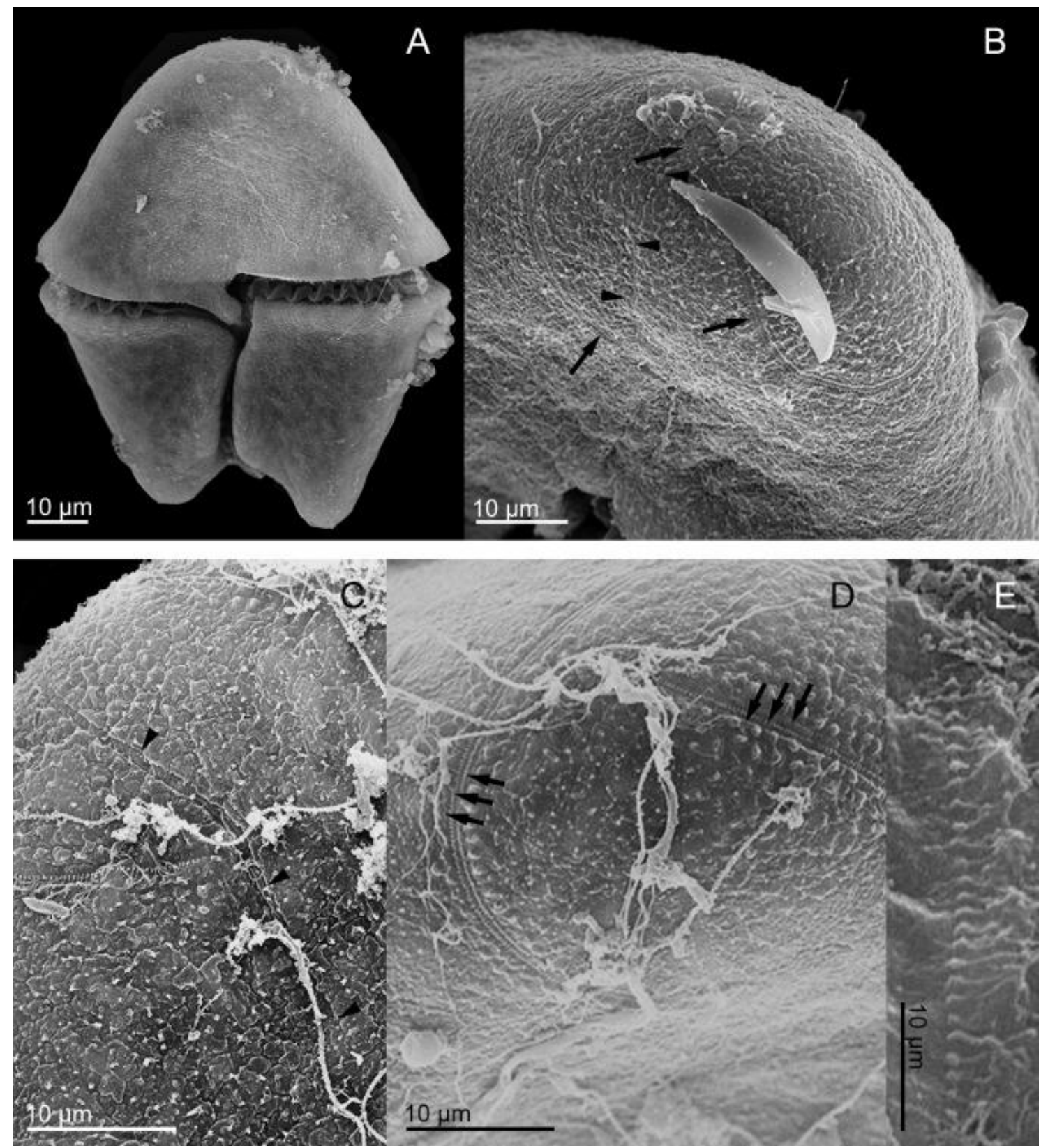
Figure 3. Diagrammatic illustration of the apical structure complex (solid line) and the sulcal intrusion (dashed line). Inset shows the detail of three rows of vesicles (marked as 1,2 and 3) with small knobs in the middle row.

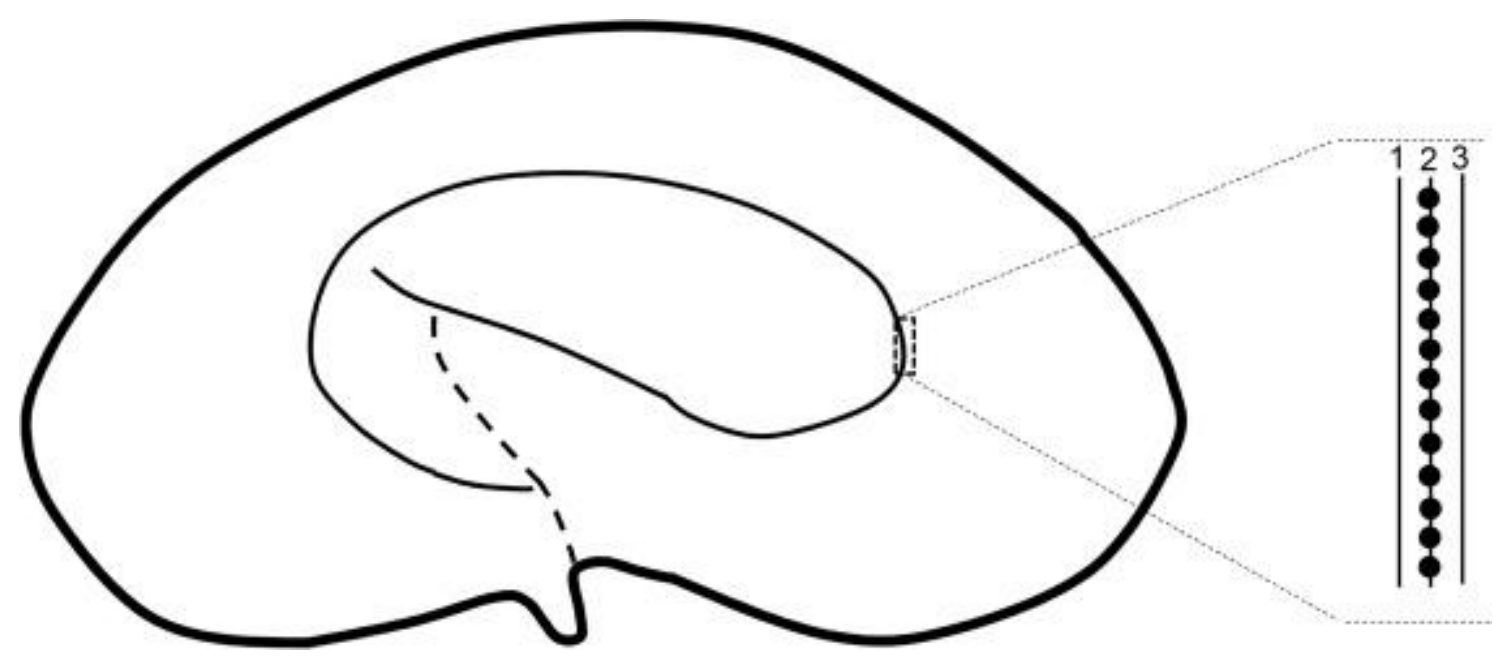


Figure 4. Molecular phylogeny of Akashiwo sanguinea inferred from partial large subunit rDNA sequences based on Bayesian inference (BI) showing four ribotypes. Numbers on branches are statistical support values to clusters on the right of them (left: maximum likelihood bootstrap support values; right: Bayesian posterior probabilities). Posterior probability $(>0.8)$ for BI support/Bootstrap value $(>50 \%)$ for maximum likelihood are shown. New sequences are indicated in bold.

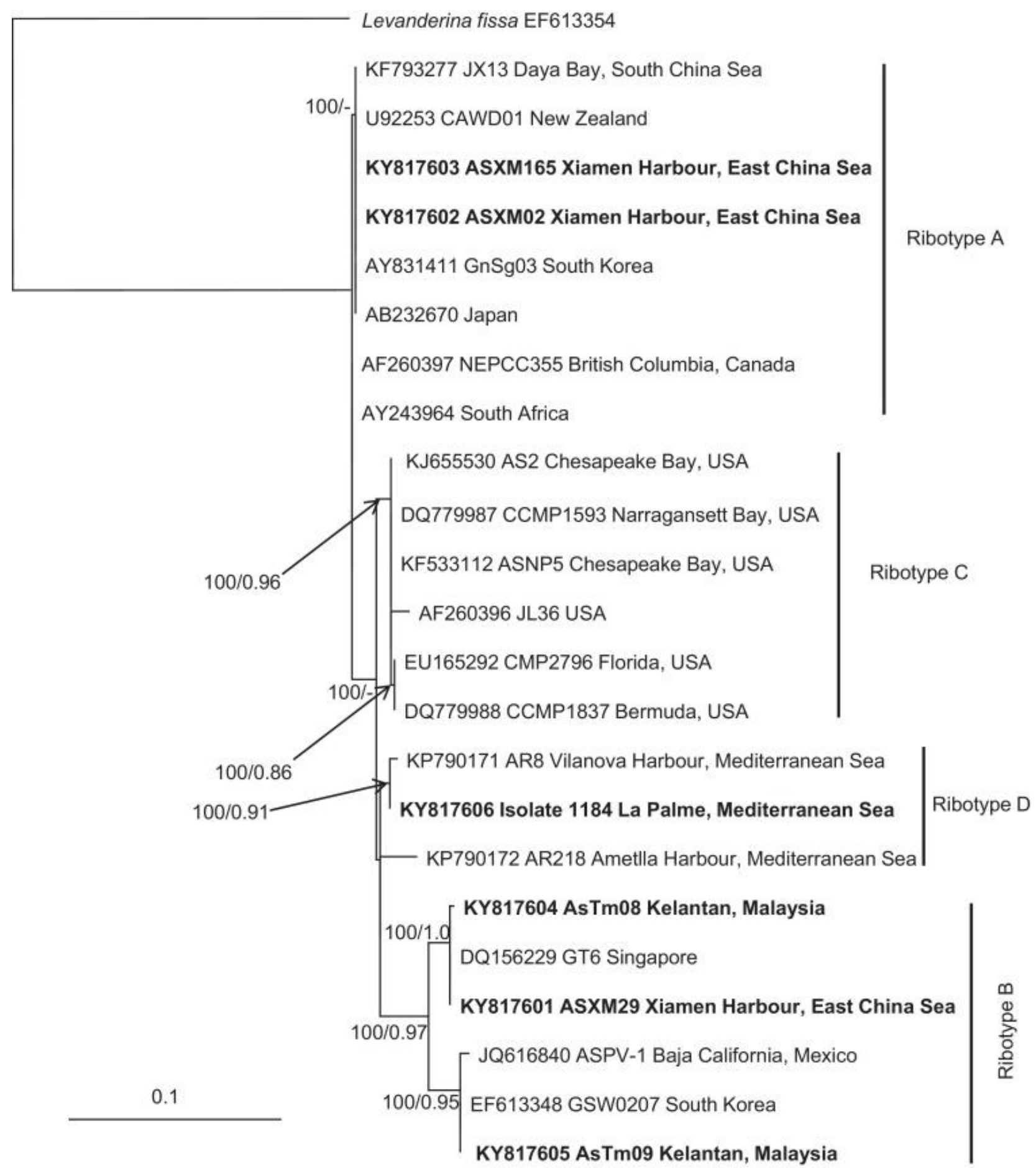


Figure 5. Seasonal occurrence of Akashiwo sanguinea ribotypes A and B in Xiamen Harbour between 2010 and 2012, showing the relative percentage of ribotypes (Ribotype A: black columns; Ribotype B: white columns) and cell numbers (circles) examined.

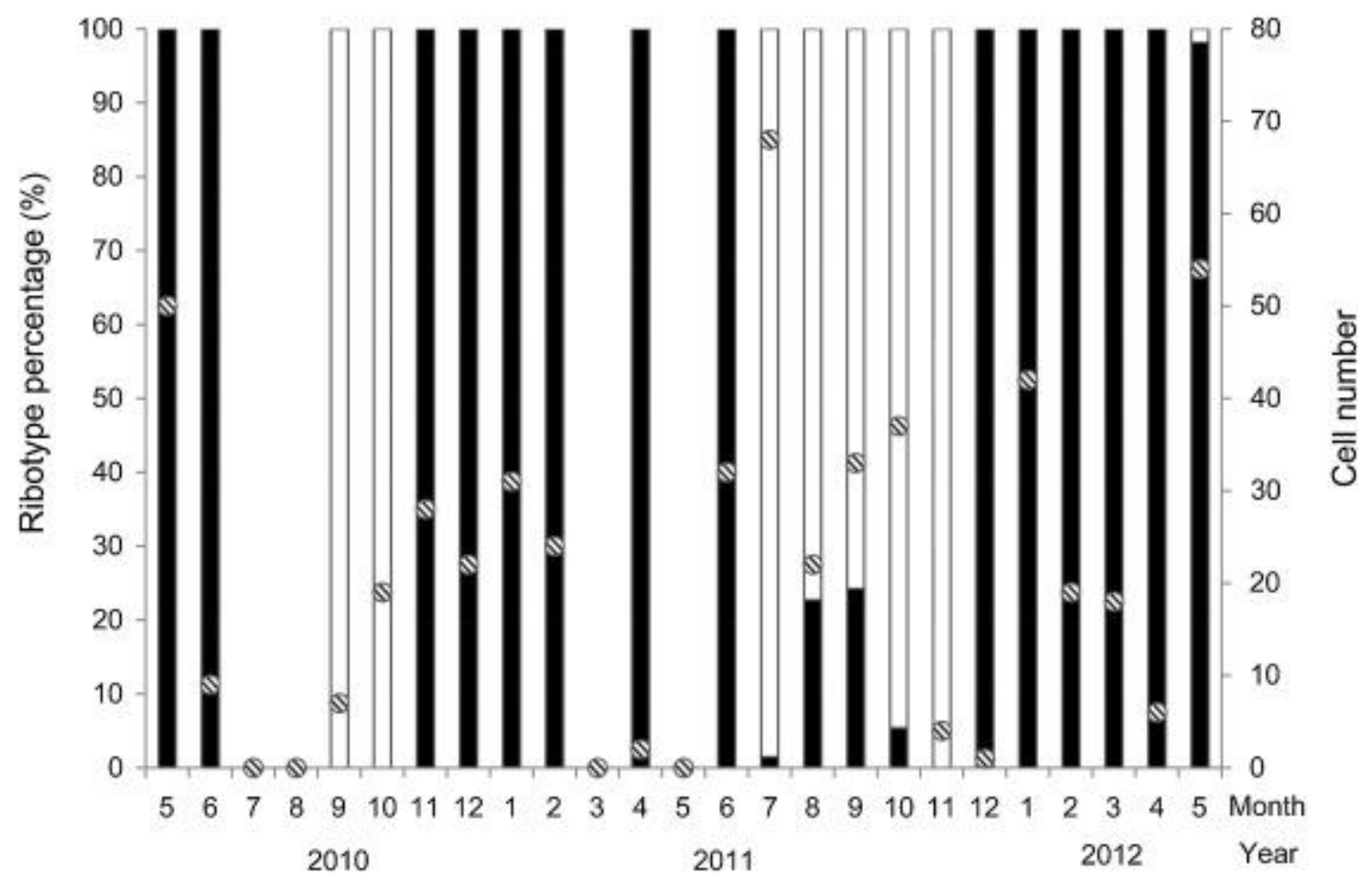


Figure 6. Growth of Akashiwo sanguinea ribotypes A (ASXM165) and B (ASXM29) under various temperatures.

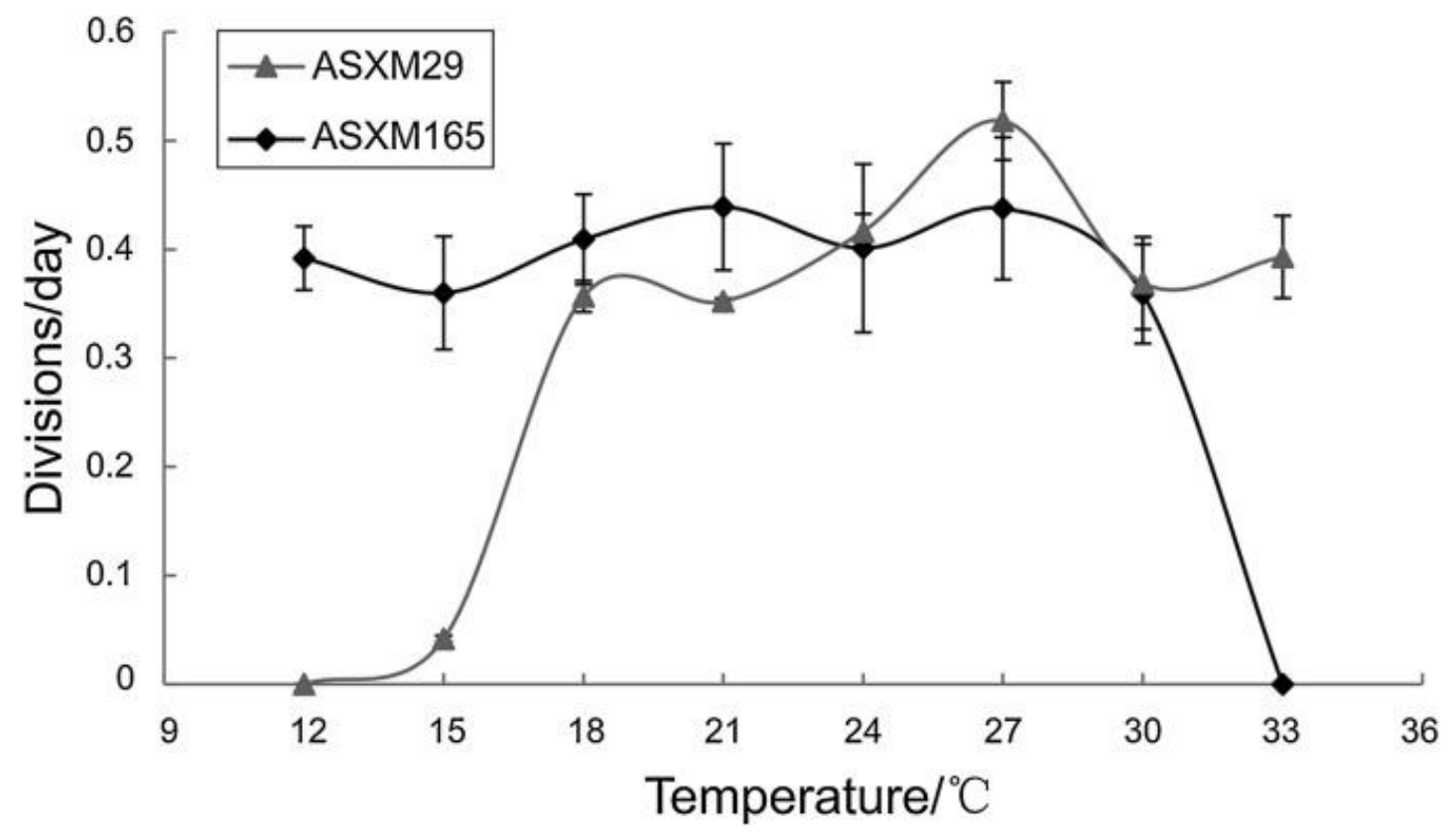


Figure S1. Map of sampling stations where Akashiwo sanguinea strains were established.

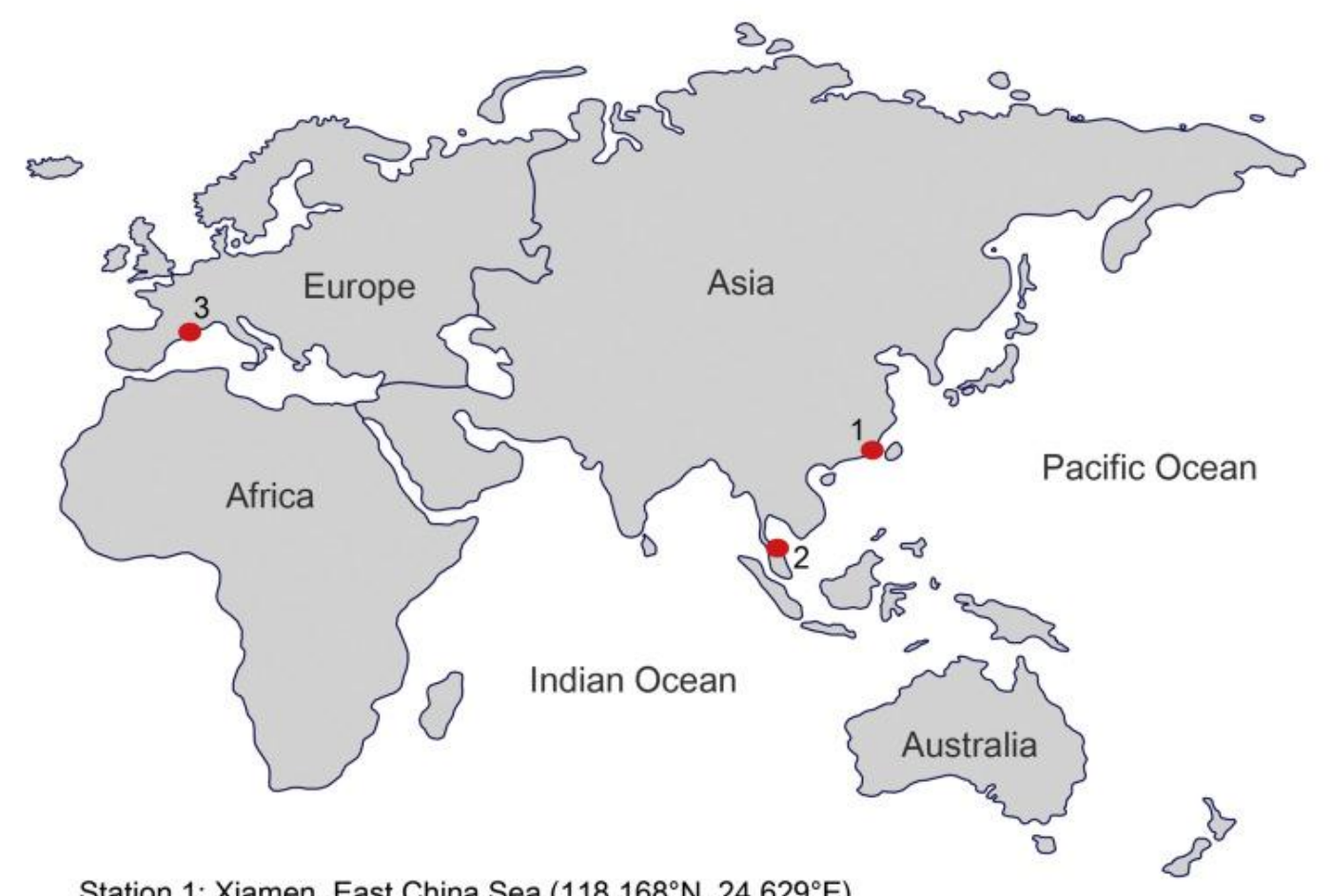

Station 1: Xiamen, East China Sea $\left(118.168^{\circ} \mathrm{N}, 24.629^{\circ} \mathrm{E}\right)$

Station 2: Kelantan, Malaysia $\left(6.244^{\circ} \mathrm{N}, 102.092^{\circ} \mathrm{E}\right)$

Station 3: Lagoon La Palme, Mediterranean Sea $\left(42.966^{\circ} \mathrm{N}, 3.006^{\circ} \mathrm{E}\right)$ 
Figure S2. Monthly variation of seawater temperatures in Xiamen Harbour from 2010 to 2012.

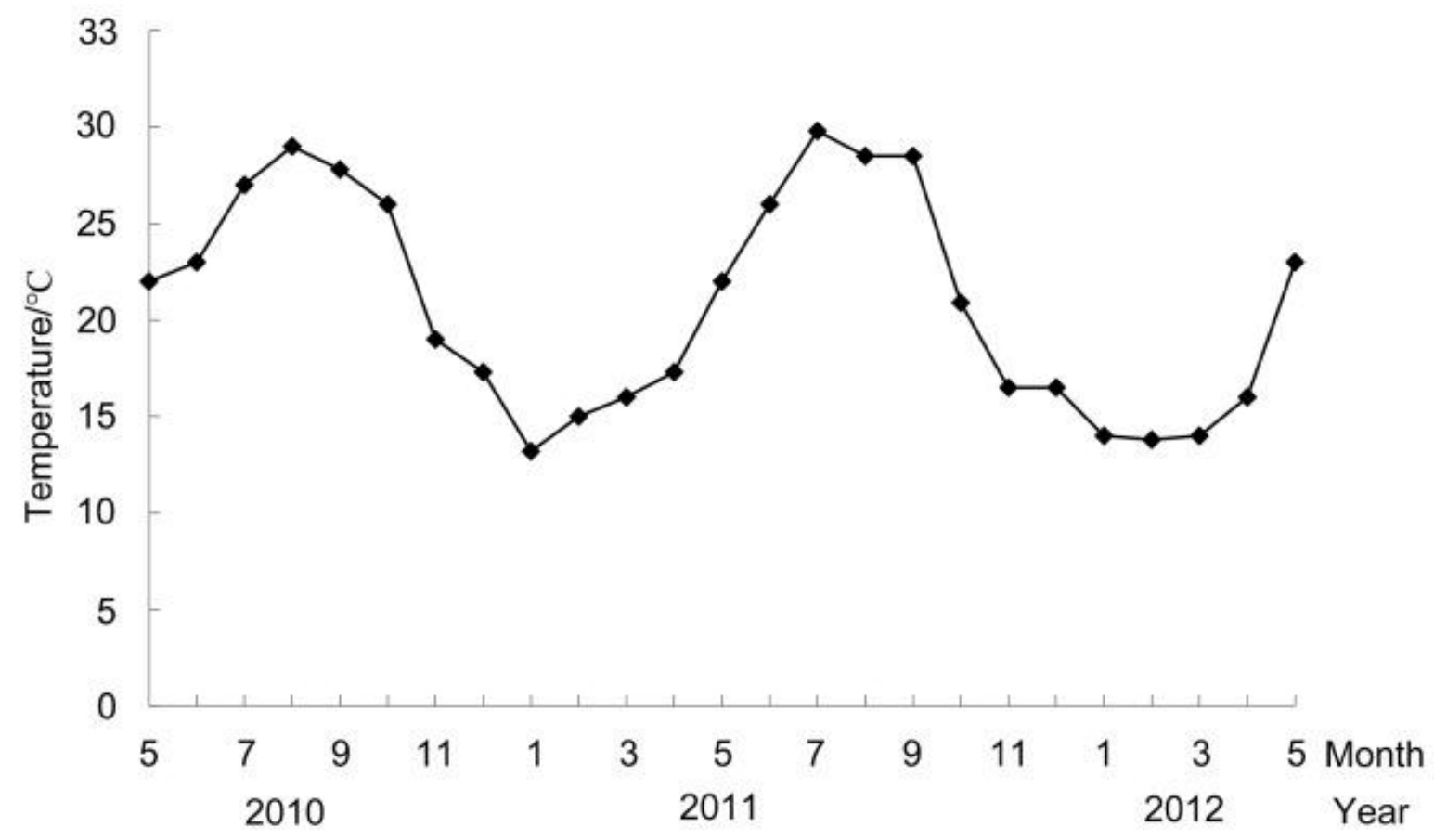

